\title{
Post-Kyoto Global Emissions Trading: Perspectives for Linking National Emissions Trading Schemes with the EU ETS in a Bottom-Up Approach
}

\author{
Sebastian Goers, Barbara Pflüglmayer
}

Energy Institute, Johannes Kepler University of Linz, Linz, Austria.

Email: goers@energieinstitut-linz.at

Received September $18^{\text {th }}, 2012$; revised October $25^{\text {th }}, 2012$; accepted November $7^{\text {th }}, 2012$

\begin{abstract}
The analysis at hand constitutes a legal, institutional and in particular qualitatively economic assessment of a global climate change policy architecture evolving from the linkage of the European Emissions Trading Scheme (EU ETS) with emerging domestic emissions trading schemes (ETS) worldwide. Initially, the marked-based climate change regimes on global as well as on EU level are reviewed. The efficiency of the complex negotiation process at the global level is assessed by its outcome according to international law. The analysis of EU legislation sets the stage for deducing essential criteria as provisions for an effective linking with other national ETS. These critical design issues are then revealed for each linking candidate in order to evaluate the linking potentials of specific domestic ETS. Moreover, the results of this multi-dimensional approach enable statements on the economic efficiency and ecological effectiveness. In particular the inefficiencies of centralized and decentralized regimes are analyzed. Due to these findings subsequent challenges for a fair and effective allocation of allowances in a bottom-up system without a centralized institution responsible for the limitation of the total amount of certificates are dealt with. As starting point for a discussion on conceivable legal constructions thereto the latter may play a role within the negotiation process towards future climate change combat strategies and agreements.
\end{abstract}

Keywords: Post-Kyoto; Emissions Trading Schemes; Bottom-Up Linking

\section{Introduction: The Rise and Fall of the Kyoto-Protocol}

As for the time being the odds are not very promising for a follow-up treaty to the Kyoto Protocol (KP) beyond 2012. Although the United Nations Climate Change Conference in Durban in 2011 has agreed to prepare a legally binding and comprehensive agreement by 2015 which shall enter into force by 2020 , there will be only self-imposed greenhouse gas (GHG) reduction targets based on the Copenhagen Accords ${ }^{1}$ in the short term. Thus, the question arises whether and which alternatives for a global climate policy exist, allowing the continued application of such market-based mechanisms. For a start a short glance is cast at the performance of international climate policy up to now.

\subsection{International Climate Policy in a Nutshell}

Figure 1 illustrates that climate protection on a global

${ }^{1}$ FCCC/SB/2011/INF.1/Rev.1, p. 3. Compilation of economy-wide emission reduction targets to be implemented by Parties included in Annex I to the Convention. level comprises a quite complex system of institutionalized multilateral negotiations. Initially, they dealt with a wide range of globally important environmental and humanitarian problems at the earth summit in Rio de Janeiro. With the adoption of the United Nations Framework Convention on Climate Change (UNFCCC) the international community of states finally agreed on particular efforts for abating climate change by reducing the global GHG-emissions. As, in fact, the UNFCCC with 195 Parties has near universal membership, it has to be considered as the starting point of a protracted process of global climate politics on the one hand and the parent treaty of the Kyoto Protocol from 1997 on the other hand.

With the entry into force of the Kyoto-Protocol on 16 February, 2005 its GHG-reduction targets actually have become legally binding on a global level for the first time. Moreover, an important shift to the application of market-based policy instruments has taken place by the introduction of the international emissions trading (IET) and the flexible instruments Joint Implementation (JI) and Clean Development Mechanism (CDM) according to 


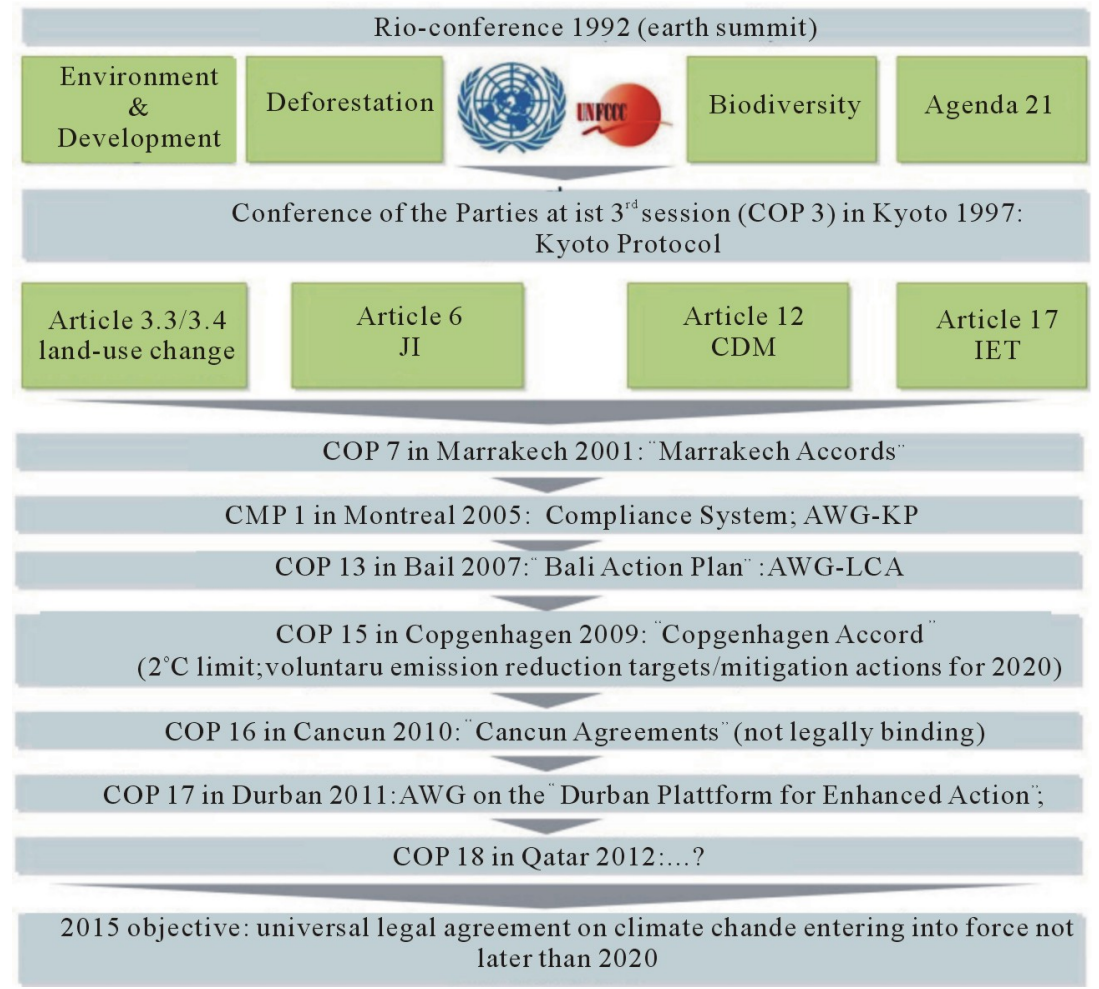

Figure 1. Simplified structure of the UNFCCC-regime and its negotiation pathway(s); Source: Own composition.

this internationally binding treaty.

Besides the above mentioned marked-based instruments the UNFCCC-regime comprises numerous additional mechanisms and programmes aiming at the achievement of the overall political target of a 2-degree limitation to global temperature rise. Hence, a constitutive connection with other important tasks of the Rio-agenda cannot be denied. Missing an appropriate consensus when the KP has been adopted, the latter only contains certain objectives for the subsequent legal implementation. Important examples in this regard are:

- Reducing Emissions from Deforestation and Forest Degradation (REDD, meanwhile enhanced to REDD+),

- Technology Mechanism (established by the Cancun agreements ${ }^{2}$,

- Adaption Fund Board (Article 12, paragraph 8 KP), and

- Green Climate Fund (established in Durban).

All in all, the UNFCCC regulations represent a complex and highly branched network of climate change abatement measures where each aspect of climate change encounters a separate solution and almost each of these approaches entails the establishment of a corresponding institution again. Creating the impression of an almost confusing aggregation of starting-points today, a future aspired really comprehensive follow-up treaty will, on

\footnotetext{
${ }^{2}$ Paragraph 117 of Decision 1/CP.16.
}

the one hand, certainly have to tackle the challenge of structural simplification, e.g. starting with the consolidation of the "two-track" negotiation process characterized by more or less parallel proceedings of the Ad Hoc Working Group on Further Commitments for Annex I Parties under the Kyoto Protocol (AWG-KP) and the Ad Hoc Working Group on Long-term Cooperative Action (AWG-LCA) as stated by [1]. On the other hand the question of international equity has to be answered more sufficiently.

That is affected e.g. by the phenomenon of the so called "low-hanging fruits" which means that the favoured use of flexible mechanisms like CDM restricts the availability of low-cost abatement measures of developing countries in the future. Unless the principle of "common but differentiated responsibilities and respecttive capabilities" as already proclaimed in the Berlin Mandate is not sincerely taken into consideration in this regard as well as in the context of the global allocation of climate change mitigation burdens and development opportunities, the prospects for gaining a new global climate treaty look rather poor.

\section{2. "Bottom-Up" Climate Policies: Paradigm Shift or Temporary Solution}

In a way all climate law, including the UNFCCC and the Kyoto-Protocol, might be subsumed under the term 
"bottom-up", since there is no world government or other centralized authority that imposes obligations upon states. Accordingly, it is necessary to clarify and define the usage of this important term in the analysis at hand: the notion of "bottom-up" in the present context refers to initiatives taking place at lower scales of organization than the international level. This interpretation is in line with other contributions cited by $[2$, p. 462] that describe this trend in climate law as "polycentric", "multilevel" or "sub-global" regulations for instance.

Thus, the legal framework imposed by the international community of states within the UNFCCC negotiation process is regarded as top-down regulation in this context anyway.

Against the backdrop of uncertainty about a follow-up treaty the prevailing dynamic in international climate policy has already changed with the Copenhagen Accord. The top-down specification of targets has then been succeeded by a "bottom-up" oriented approach whereby countries submit their own pledges concerning their envisaged national emissions reductions.

More and more countries try to reach their self-imposed GHG-targets by implementing national emissions trading systems. From an economic point of view, the global linkage of as many domestic emission trading schemes as possible is expected to increase efficiency and reduce abatement costs in the first place. Moreover, the problem of "carbon leakage" is the further diminishing the more countries are involved in a coordinated climate regime.

After outlining qualitatively the essential requirements of such an alternative bottom-up approach, an overview and a classification of potential candidates for linking are provided. In Section 4 the future prospects of the assumed paradigm shift to such a bottom-up approach will finally be critically reviewed.

\section{Key Design Issues for Linkages with the EU ETS}

As far as factual emission reductions are concerned the European ETS can be considered as quite successful for the time being. However, in a critical view, it has to be admitted that a good deal of the accounted reductions are due to flexible instruments like JI and CDM and therefore they have to be regarded at least sceptically. ${ }^{3}$

The EU ETS contains a legal provision offering the explicit option for linking with other domestic ETS in Article 25 of the ETS Directive ${ }^{4}$ itself. After its revision

\footnotetext{
${ }^{3}$ Remember e.g. the "low-hanging fruits" mentioned in Section 2 above. ${ }^{4}$ Directive 2003/87/EC of the European Parliament and of the Council of 13 October 2003 establishing a scheme for greenhouse gas emission allowance trading within the Community as amended by Directive 2004/101/EC, Directive 2008/101/EC, Regulation (EC) No 219/2009 and Directive 2009/29/EC.
}

in the course of the EU climate and energy package in 2009 , the additional paragraph 1a specifies that "agreements may be made to provide for the recognition of allowances between the Community scheme and compatible mandatory greenhouse gas emission trading systems with absolute emissions caps established in any other country or in sub-federal or regional entities" which will enter into force at the beginning of 2013.

Accordingly [3] highlight a key role by the EU in the process of linking provided that a potential linking candidate meets certain quality criteria. Hence, the European scheme has been looked at and particularly analyzed with regard to such characteristic elements that are critical for other domestic ETS for linking with the EU-ETS. ${ }^{5}$ Following [4] the conditions for a successful linking of ETS are defined by the degree of consistency of the different schemes. Table 1 provides an overview of the considered key design issues which are assessed regarding their characteristics for linking (with the EU ETS).

Recalling the above mentioned key design elements the following requirements are crucial in order to provide economic efficiency and ecological effectiveness of a linked ETS:

- The participation is mandatory for all relevant emitters, and all important emissions and sectors are covered by the scheme.

- The cap is designed absolutely and stringently and displays serious but realistic ecological targets.

- Allocation is achieved by auctioning whereas temporal flexibility is induced and guaranteed by the possibility of linking, but no unrestricted borrowing is allowed.

- Ecologically ambitious offsets are accepted for compliance only to a certain degree whereas price caps may endanger the ecologic and economic performance depending on the actual carbon price.

- Monitoring, reporting, verification and registry are operated via electronic systems.

- Penalty frameworks contain a monetary fine and the obligatory delivery of missing allowances.

\section{Potential Linking Candidates}

\subsection{Existing and Planned ETS-An Overview}

Various ETS are already in place around the world, are being planned or enter into an important stage of design. The following existing and planned ETS in 2012, as illustrated in Figure 2, are examined with regard to the above discussed key design elements:

- ETS of Switzerland,

- Japan Voluntary Emission Trading Scheme (JVETS),

- Japan-Integrated Domestic Market of Emissions,

${ }^{5}$ Based on the legal rules for the up-coming trading period 2013-2020. 
Table 1. Key design elements and implications for linking-Overview.

\begin{tabular}{|c|c|c|c|c|c|}
\hline \multicolumn{2}{|c|}{ Key design elements } & Possible linking effects \& obstacles & $\begin{array}{l}\text { Economic } \\
\text { efficiency }\end{array}$ & $\begin{array}{l}\text { Environmental } \\
\text { effectiveness }\end{array}$ & $\begin{array}{l}\text { Consistency } \\
\text { with EU ETS }\end{array}$ \\
\hline \multirow{4}{*}{$\begin{array}{l}\text { Scheme's } \\
\text { coverage }\end{array}$} & Gas coverage & $\begin{array}{l}\text { Linking to an ETS with a broader (lower) } \\
\text { coverage } \rightarrow \text { abatement options } \uparrow(\downarrow)\end{array}$ & basically given & basically given & $\begin{array}{l}\text { desirable } \\
\text { but not } \\
\text { essential }\end{array}$ \\
\hline & Sector coverage & $\begin{array}{l}\text { Double-counting is possible, competition } \\
\text { concerns may arise }\end{array}$ & basically given & basically given & $\begin{array}{l}\text { desirable } \\
\text { but not } \\
\text { essential }\end{array}$ \\
\hline & $\begin{array}{l}\text { Manda- } \\
\text { tory/voluntary }\end{array}$ & $\begin{array}{l}\text { Voluntary market may induce leakage and } \\
\text { entrance of net allowance sellers }\end{array}$ & highly at risk & highly at risk & essential \\
\hline & $\begin{array}{l}\text { Direct/indirect } \\
\text { emissions }\end{array}$ & $\begin{array}{l}\text { Double-counting is possible, competition } \\
\text { concerns may arise }\end{array}$ & basically given & basically given & $\begin{array}{l}\text { desirable } \\
\text { but not } \\
\text { essential }\end{array}$ \\
\hline \multicolumn{2}{|c|}{$\begin{array}{l}\text { Definition and recognitions } \\
\text { of trading units }\end{array}$} & $\begin{array}{l}\text { Mal-functioning legal framework may } \\
\text { disable a fair recognition, trading and } \\
\text { eligibility of diverse units }\end{array}$ & basically given & basically given & $\begin{array}{l}\text { desirable } \\
\text { but not } \\
\text { essential }\end{array}$ \\
\hline \multirow[b]{2}{*}{ Cap setting } & $\begin{array}{l}\text { Absolute/ } \\
\text { relative caps }\end{array}$ & $\begin{array}{l}\text { Total emissions of ETS with relative cap are } \\
\text { not known in advance } \rightarrow \text { Liquidity of } \\
\text { allowance } \downarrow\end{array}$ & highly at risk & highly at risk & essential \\
\hline & Stringency of caps & $\begin{array}{l}\text { Significant wealth transfers between linking } \\
\text { partners in case of non-comparable } \\
\text { stringency levels }\end{array}$ & $\begin{array}{l}\text { basically given } \\
\text { (if overall cap is } \\
\text { stringent) }\end{array}$ & $\begin{array}{l}\text { basically given } \\
\text { (if overall cap is } \\
\text { stringent) }\end{array}$ & $\begin{array}{l}\text { politically } \\
\text { required }\end{array}$ \\
\hline \multicolumn{2}{|c|}{ Allocation Methodology } & $\begin{array}{l}\text { Differences may occur because of subsequent } \\
\text { allocation rules that imply distributional } \\
\text { impacts }\end{array}$ & given & $\begin{array}{l}\text { basically given } \\
\text { (if overall cap is } \\
\text { stringent) }\end{array}$ & $\begin{array}{l}\text { desirable } \\
\text { but not } \\
\text { essential }\end{array}$ \\
\hline \multirow{3}{*}{$\begin{array}{l}\text { Temporal } \\
\text { Flexibility }\end{array}$} & Continuance & $\begin{array}{l}\text { Same continuance levels are necessary } \\
\text { regarding credibility and commitment }\end{array}$ & highly at risk & highly at risk & essential \\
\hline & Banking & $\begin{array}{l}\text { Market and competition distortions in case of } \\
\text { heterogeneous banking rules }\end{array}$ & basically given & basically given & $\begin{array}{l}\text { politically } \\
\text { essential }\end{array}$ \\
\hline & $\begin{array}{l}\text { (unrestricted) } \\
\text { Borrowing }\end{array}$ & $\begin{array}{l}\text { Destabilisation of penalty and } \\
\text { compliance system }\end{array}$ & highly at risk & highly at risk & essential \\
\hline \multicolumn{2}{|c|}{$\begin{array}{l}\text { Monitoring, reporting and } \\
\text { verification }\end{array}$} & $\begin{array}{l}\text { In equally stringent frameworks rigorous } \\
\text { monitoring processes and robust basis for } \\
\text { verification and calculations by equal MRV } \\
\text { standards }\end{array}$ & basically given & $\begin{array}{l}\text { basically given } \\
\text { (if systems are } \\
\text { equally stringent) }\end{array}$ & $\begin{array}{l}\text { not essential } \\
\text { if systems are } \\
\text { equally } \\
\text { stringent }\end{array}$ \\
\hline \multirow{3}{*}{$\begin{array}{l}\text { Compliance } \\
\text { and penalty } \\
\text { framework }\end{array}$} & Use of offsets & $\begin{array}{l}\text { Market and competition distortions in case of } \\
\text { heterogeneous crediting rules, eligibility } \\
\text { criteria and quantitative limits }\end{array}$ & basically given & basically given & $\begin{array}{l}\text { politically } \\
\text { required }\end{array}$ \\
\hline & Penalty system & $\begin{array}{l}\text { In equally stringent frameworks, high } \\
\text { penalties lead to incentives to } \\
\text { reduce } \mathrm{CO}_{2} \text { emissions }\end{array}$ & $\begin{array}{l}\text { basically given } \\
\text { (if systems are } \\
\text { equally stringent) }\end{array}$ & $\begin{array}{l}\text { basically given } \\
\text { (if systems } \\
\text { are equally } \\
\text { stringent) }\end{array}$ & $\begin{array}{l}\text { not essential } \\
\text { if systems are } \\
\text { equally } \\
\text { stringent }\end{array}$ \\
\hline & Price cap & $\begin{array}{l}\text { Price cap will be applied in the overall } \\
\text { linked systems }\end{array}$ & highly at risk & highly at risk & essential \\
\hline
\end{tabular}

Source: Own composition, partly based on [4]. 


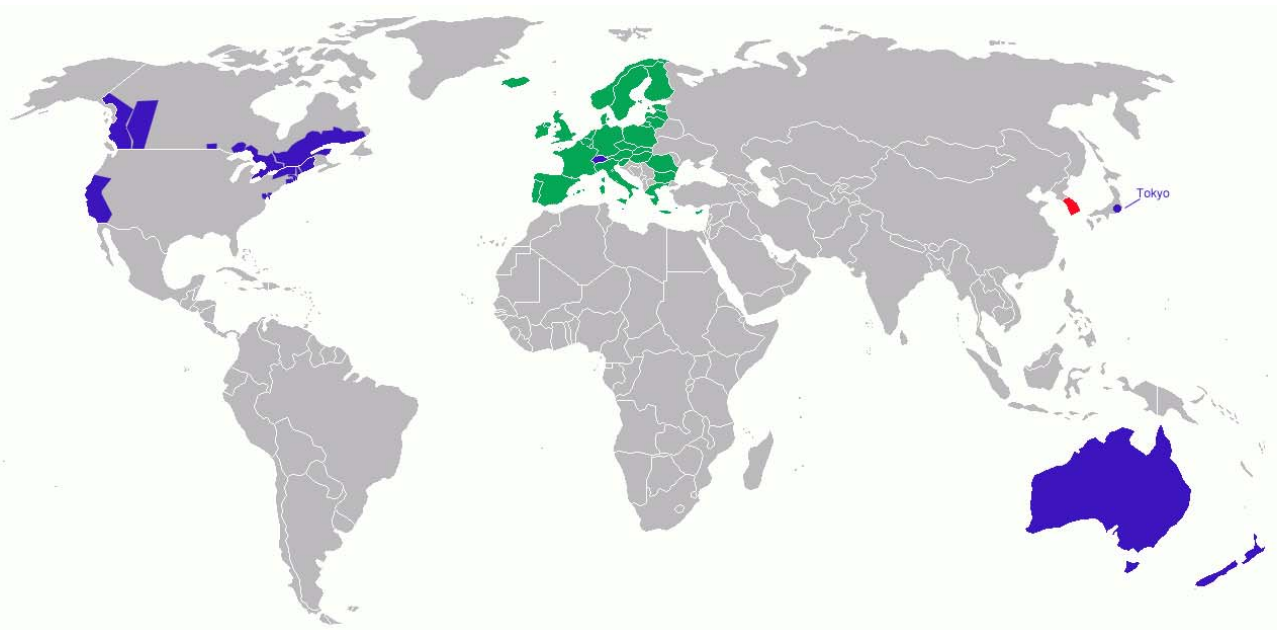

Figure 2. Evaluated emissions trading schemes; Note: EU ETS is displayed in green color, operating ETS are displayed in blue color and planned ETS are displayed in red color; Source: Own compilation.

Trading (IDMET),

- Tokyo ETS,

- South Korea ETS,

- Australia-Carbon Price Mechanism (CPM),

- New Zealand ETS,

- USA-Regional Greenhouse Gas Initiative (RRGI),

- USA and Canada - Western Climate Initiative (WCI),

- USA/California - Global Warming Solutions Act of 2006 (GWSA),

- Canada/Alberta: Greenhouse Gas Reduction Program. The authors are aware that this does not represent a complete overview. Because of the lack of publicly available information, particular ETS cannot be considered for the analysis ([5], pp. 29-30):

- Brazil,

- China,

- Ukraine/Russia/Kazakhstan/Belarus,

- Chile,

- Turkey,

- Mexico.

The New South Wales Greenhouse Gas Reduction Scheme (GGAS) was closed by July 2012.

As far as the United States of America is concerned, all imposed initiatives are regionally negotiated to fix a model rule and are then implemented on state level. In this regard the RGGI and the WCI are examined, with California being analyzed as an example of a WCI member state. The Chicago Climate Exchange, a voluntary but legally binding emission trading system, is also not taken into consideration as it was closed in 2010 . Federal legislative proposals on climate and energy in the US Congress, such as the Waxman-Markey Bill, the Kerry-Boxer Bill and the Kerry-Liebermann Bill were also not evaluated as their entry into force is rather improbable.

\subsection{Identification of Linking Candidates}

In economic terms the central principles of climate policy in the context of linking are the generation of economic efficiency by an overall cost-minimisation and by environmental effectiveness through the decrease of GHG emissions as defined by the reduction target.

In order to identify serious candidates for a reasonable bottom-up approach, the selected schemes have been studied with regard to the revealed key design elements where consistency with the EU ETS is essential for an economically efficient and environmentally effective linking.

As stated in Table 1, the combination of voluntary and mandatory systems may induce the leakage of emitters facing a high abatement burden of the voluntary scheme, and hence, economic efficiency and environmental integrity may be highly at risk. Further, the voluntary market may attract net sellers of allowances, which weakens the cap's overall stringency and in turn endangers environmental effectiveness. In Japan the system shall be understood as a pilot project which helps to gain information about building up national emission trading schemes. Absolute ecological effectiveness and $\mathrm{CO}_{2}$ price signals are not significant regarding environmental regulation at national and international level. Regarding the linkage of the JVETS and the IDMET with the EU ETS, the voluntary character of these two Japanese systems would reduce ecological and economic benefits induced by linking. Hence, the incentives to connect these systems to larger and stricter markets might not be existent in the present assuming the perpetuation of the schemes' design.

Another crucial aspect for successful linking is the cap's design. In case of a combination of relative and 
absolute caps the fact that total emissions of the system with the relative cap are not known in advance harms the market liquidity. In addition, [6] points out that in case of linking systems with absolute and relative targets there may be a feedback in the overall emissions of the scheme with a relative cap disabling ecological effectiveness. For those reasons, the Greenhouse Gas Reduction Programme of Alberta should be excluded from further analysis.

Thirdly, continuance builds an essential element when systems are linked. The combination of schemes in case of unclear expiration dates and legislation reduces credibility in the permanence of compliance and serious abatement burdens for covered sectors. The evaluated schemes mostly feature time-scales until 2020. The linking of the considered schemes in the mid and the long term may strengthen the negotiation process, regarding the globally binding climate agreement focused on by the UNFCCC as a follow-up treaty to the KP, which shall enter into force in 2020.

Fourthly, unrestricted borrowing of allowances within one linking partner scheme would destabilise the overall penalty and compliance system. As a result, economic efficiency and ecological integrity might be highly at risk because the obligation to reduce could be unlimitedly transferred to future periods. Within the analysed ETS, only the IDMET, which already was disqualified from further analysis because of its voluntary character, featured unrestricted borrowing.

It was also derived in Table 1 that in case of linking the EU ETS to schemes with price caps, the safety valve will be applied in the linked system. This means that depending on the level of this price cap economic efficiency and environmental integrity in the EU ETS might be endangered. The analysis of the existing and planned ETS showed that the operating ETS of New Zealand features a price cap of $25 \mathrm{NZ \$ /tCO} 2\left(\sim 16 € / \mathrm{tCO}_{2}\right)$ from 2012 and the planned Australian CPM features a price cap of $20 \mathrm{~A} \$ / \mathrm{tCO}_{2}\left(\sim 16 € / \mathrm{tCO}_{2}\right)$ above the international carbon market price from 2016. In Switzerland, sources which are not covered by the domestic ETS are regulated by a $\mathrm{CO}_{2}$ tax which imposes $36 \mathrm{CHF} / \mathrm{tCO}_{2}\left(\sim 30 € / \mathrm{tCO}_{2}\right)$. As the participation in the Swiss ETS is a voluntary alternative to the mandatory $\mathrm{CO}_{2}$ tax, the tax can also be understood as the price cap of the ETS. Regarding the $\mathrm{CO}_{2}$ price generated by the EU ETS, a level of $6-8$ $€ / \mathrm{tCO}_{2}$ was ultimately achieved during spring 2012 . Assuming similar price levels in the third trading period, the mentioned price caps would not put the ecologic and economic performance of a linked approach at risk.

On the other hand, a higher positive price signal $(\geq 16$ $\left.€ / \mathrm{tCO}_{2}\right)$ in the EU ETS would weaken the benefits of a linkage with the ETS of New Zealand.
From the analyses as disclosed in Tables 2-4 a basic linking scenario is derived. It is defined by the combination of the EU ETS with the following linking candidates: ETS of Switzerland, Tokyo ETS, South Korea ETS, Australia CPM, New Zealand ETS, USA-Regional Greenhouse Gas Initiative, USA and Canada-Western Climate Initiative and USA/California-Global Warming Solutions Act of 2006. As Figure 3 displays, in this scenario the linked system covers approx. $4200 \mathrm{MtCO}_{2} \mathrm{e}$. As the Australian scheme fixes the allowance price within the first three years of trading, a linkage in the short term is not possible. However, an efficient cap-and-trade design is focused from July 2015, turning Australia into a serious linking partner.

\section{From Global Commons to Global Governance}

On the one hand, from an economic point of view linking the EU ETS and other existing or emerging domestic ETS is highly desirable, because a linkage between two or more ETS will generate a market with a larger number of participants, increasing the diversity of control costs and increasing the liquidity of the market [7]. This will further contribute to reducing the overall cost of compliance in the concerned systems while improving the overall economic efficiencies of the ETS. Furthermore, linking ETS also provides internationally competing companies a wider regulatory framework with a single price of carbon. Finally, an ETS linkage does not only promote technology transfer and sustainable development, but also the creation of a larger global market [8].

On the other hand, the risk that the cap setting process of the linking partners turns into a multi-stage game with strategically acting states cannot be denied. This again may increase the overall cap and reduce the total abatement and lead to lower economic efficiency and ecological effectiveness as compared to a situation without linkage.

Hence, a polycentric climate governance approach system will also require a central authority to a certain extent-in particular concerning the allocation of allowances and compliance. The crucial point is eventually, how to limit the amount of certificates in a fair and also effective way-so that the ecologically necessary climate change mitigation is promoted.

A solution may be found in the area of global governance which can be defined as governing beyond the nation state. Governance without government indicates that activities at the international level are characterized by shared goals but are not backed by a formal legal authority. The focus of global governance is thus on cooperation and harmonization in order to attain compliance. 
Schemes with the EU ETS in a Bottom-Up Approach

Table 2. General issues of different emissions trading schemes.

\begin{tabular}{|c|c|c|c|c|c|c|}
\hline & $\begin{array}{c}\text { Level of } \\
\text { implementation }\end{array}$ & Starting date & $\begin{array}{l}\text { Time scale/ } \\
\text { continuance }\end{array}$ & $\begin{array}{l}\text { Participating } \\
\text { countries }\end{array}$ & $\begin{array}{l}\text { Relative/ } \\
\text { absolute } \\
\text { cap }\end{array}$ & Cap \\
\hline $\begin{array}{c}\text { ETS } \\
\text { Switzerland }\end{array}$ & Operating & $1^{\text {st }}$ January 2008 & $2008-2012$ & Switzerland & absolute & $\begin{array}{l}8 \% \text { reduction of } 1990 \text { levels } \\
\text { 2008: } 3.3 \mathrm{MtCO}_{2}, 2009: 3.1 \\
\mathrm{MtCO}_{2}, 2010: 3.4 \mathrm{MtCO}_{2}\end{array}$ \\
\hline JVETS & Operating & $1^{\text {st }}$ January 2005 & since 2005 & Japan & absolute & $\begin{array}{c}\text { 2005: } 1.3 \mathrm{MtCO}_{2}, 2006: 1.1 \mathrm{MtCO}_{2} \text {, } \\
\text { 2007: } 1.6 \mathrm{MtCO}_{2}, 2008: 3.4 \mathrm{MtCO}_{2} \text {, } \\
\text { 2009: } 0.6 \mathrm{MtCO}_{2}\end{array}$ \\
\hline IDMET & Operating & Autumn 2008 & 2008-2012 & Japan & $\begin{array}{l}\text { Absolute/ } \\
\text { relative }\end{array}$ & $\begin{array}{c}50 \% \text { of Japanese } \mathrm{CO}_{2} \text { emissions, } \\
70 \% \text { of the Japanese industry's } \\
\mathrm{CO}_{2} \text { emissions }\end{array}$ \\
\hline Tokyo ETS & Operating & $1^{\text {st }}$ April 2010 & since 2010 & $\begin{array}{l}\text { Tokyo } \\
\text { (Japan) }\end{array}$ & absolute & $\begin{array}{c}\text { 2010-2014: } 6 \% \text { reduction } \\
\text { for } 5 \text { year average } \\
\text { 2015-2019: } 17 \% \text { reduction } \\
\text { for } 5 \text { year average }\end{array}$ \\
\hline $\begin{array}{c}\text { South } \\
\text { Korea ETS }\end{array}$ & Planned & 2015 & $2015-2020$ & South Korea & absolute & $\begin{array}{l}30 \% \text { cut from "business as } \\
\text { usual" emissions by } 2020\end{array}$ \\
\hline СРM & Operating & $1^{\text {st }}$ July 2012 & $\begin{array}{l}1^{\text {st }} \text { July } 2012-30^{\text {th }} \\
\text { June } 2015 \\
\text { from } 1^{\text {st July }} \\
2015 \text { on }\end{array}$ & Australia & absolute & $\begin{array}{l}5 \% \text { cut from } 2000 \text { emissions } \\
\text { by } 2020 ; \text { from } 1^{\text {st }} \text { July } 2015 \\
\text { annual cap setting }\end{array}$ \\
\hline $\begin{array}{l}\text { New } \\
\text { Zealand } \\
\text { ETS }\end{array}$ & Operating & 2008 & $\begin{array}{l}2008-2009 \\
2009-2010 \\
2010-2012 \\
2013-2020\end{array}$ & New Zealand & absolute & $\begin{array}{l}\text { No overall reduction target; } \\
\text { emitting as long as allowances } \\
\text { are available }\end{array}$ \\
\hline RGGI & Operating & $1^{\text {st }}$ January 2009 & $\begin{array}{l}2009-2011 \\
2012-2014 \\
2015-2017\end{array}$ & $\begin{array}{l}9 \text { North-Eastern } \\
+ \text { Mid-Atlantic } \\
\text { US States }\end{array}$ & absolute & $\begin{array}{c}\text { 2009-2014: stabilisation at } 2009 \\
\text { levels; } 10 \% \text { reduction below } \\
2009 \text { levels by } 2018\end{array}$ \\
\hline WCI & Operating & $1^{\text {st }}$ January 2012 & $\begin{array}{l}2012-2014 \\
2015-2017 \\
2018-2020\end{array}$ & $\begin{array}{c}\text { California }+4 \\
\text { Canadian Provinces }\end{array}$ & absolute & $\begin{array}{c}15 \% \text { reduction below } 2005 \\
\text { levels by } 2020\end{array}$ \\
\hline GWSA & Operating & $1^{\text {st }}$ January 2012 & $\begin{array}{l}2012-2014 \\
2015-2017 \\
2018-2020\end{array}$ & California & absolute & $\begin{array}{l}15 \% \text { reduction below } 2005 \\
\text { levels by } 2020\end{array}$ \\
\hline Alberta & Operating & 2007 & since 2007 & Alberta & relative & $\begin{array}{c}\text { Annual reduction of energy } \\
\text { intensity by } 12 \%\end{array}$ \\
\hline
\end{tabular}

Source: Own compilation based on publicly available information retrieved from related governmental websites as of 30 June 2012.

\subsection{Notes on the Institutional Design of a Bottom-Up-Approach}

In principle, also in a decentralized system bilateral and/or multilateral treaties might be the main mechanism for meeting the necessary regulations, because in the context of international law this is the only way to create a binding type of cooperation. But though such agree- ments are based on reciprocal obligations and in some cases even safeguarded by the possibility of sanctions and measures to remedy default, an effective implementation still has to face several challenges.

Above all, a country's sovereignty is not limited by the conclusion of an international treaty in principle. A single state party might change its mind any time and decide to cancel its participation, as it never has lost its full 
Table 3. Coverage issues in different emissions trading schemes.

\begin{tabular}{|c|c|c|c|c|c|}
\hline & Gas coverage & Sector coverage & $\begin{array}{l}\text { Mandatory/ } \\
\text { voluntary } \\
\text { participation }\end{array}$ & $\begin{array}{l}\text { Direct/ } \\
\text { indirect } \\
\text { emissions }\end{array}$ & $\begin{array}{l}\text { Opt-in and } \\
\text { opt-out } \\
\text { provisions }\end{array}$ \\
\hline EU ETS & $\begin{array}{l}\mathrm{CO}_{2}, \mathrm{~N}_{2} \mathrm{O} \text { from } \\
\text { acid production, } \\
\text { PFCs from the } \\
\text { aluminium sector }\end{array}$ & $\begin{array}{l}\text { Power stations, combustion plants, oil } \\
\text { refineries, coke ovens, iron and steel plants } \\
\text { and factories making cement, glass, lime, } \\
\text { bricks, ceramics, pulp, paper and } \\
\text { board, aviation }\end{array}$ & Mandatory & Direct & $\begin{array}{l}\text { Opt-out for small } \\
\text { emitters and } \\
\text { hospitals from } \\
2013 \text { to } 2020\end{array}$ \\
\hline $\begin{array}{c}\text { ETS } \\
\text { Switzerland }\end{array}$ & $\mathrm{CO}_{2}$ & $\begin{array}{l}\text { Cement, pulp and paper, glass, } \\
\text { ceramic production }\end{array}$ & $\begin{array}{l}\text { Voluntary } \\
\text { alternative to } \\
\text { mandatory } \mathrm{CO}_{2} \\
\qquad \operatorname{tax}\end{array}$ & Direct & $\begin{array}{l}\text { Participation of } \\
\text { private sectors is } \\
\text { possible }\end{array}$ \\
\hline JVETS & $\mathrm{CO}_{2}$ & $\begin{array}{l}\text { energy-intensive industry, power } \\
\text { generation, transport and service }\end{array}$ & Voluntary & Direct & \\
\hline Tokyo ETS & $\mathrm{CO}_{2}$ & $\begin{array}{l}\text { Commercial buildings and industrial } \\
\text { facilities with consumption of fuels, heat } \\
\text { and electricity } \geq 1500 \mathrm{k} \mathrm{BOE}\end{array}$ & Mandatory & Direct & \\
\hline $\begin{array}{l}\text { South Korea } \\
\text { ETS }\end{array}$ & $\mathrm{CO}_{2}$ & $\begin{array}{l}\text { Industry (power generation, } \\
\text { manufacturing), buildings (universities, } \\
\text { amusement parks), waste (incineration, } \\
\text { waste water treatment), agriculture and } \\
\text { forestry }\end{array}$ & Mandatory & Direct & \\
\hline CPM & $\begin{array}{l}\mathrm{CO}_{2}, \mathrm{CH}_{4}, \mathrm{~N}_{2} \mathrm{O} \\
\mathrm{HCF}, \mathrm{PHCs}, \mathrm{SF}_{6}\end{array}$ & $\begin{array}{l}\text { Entities with emissions } \geq 25 \mathrm{k} \mathrm{tCO}_{2} \\
\text { stationary energy, industrial and fugitive } \\
\text { processes, non-legacy waste, partly } \\
\text { transport }\end{array}$ & Mandatory & Direct & $\begin{array}{l}\text { Entities acquiring, } \\
\text { generating or } \\
\text { importing } \\
\text { amounts of } \\
\text { taxable fuel }\end{array}$ \\
\hline RGGI & $\mathrm{CO}_{2}$ & $\begin{array}{l}\text { Electricity sector (fossil fuelled electric } \\
\text { power plants } \geq 25 \mathrm{MW} \text { ) }\end{array}$ & Mandatory & Direct & $\begin{array}{l}\text { Single states can } \\
\text { opt in and out }\end{array}$ \\
\hline WCI & $\begin{array}{l}\mathrm{CO}_{2}, \mathrm{CH}_{4}, \mathrm{~N}_{2} \mathrm{O} \\
\mathrm{JDCs}, \mathrm{SF}_{6} \text { and } \\
\mathrm{NF}_{3}\end{array}$ & $\begin{array}{l}\text { Electricity and Industry (facilities } \geq 25 \mathrm{k} \\
\mathrm{tCO}_{2} \mathrm{e} \text { ) from } 2012 \text {, transport, commercial } \\
\text { and residential fuel from } 2015\end{array}$ & Mandatory & $\begin{array}{l}\text { Direct and } \\
\text { indirect }\end{array}$ & $\begin{array}{l}\text { Single states can } \\
\text { opt in and out }\end{array}$ \\
\hline GWSA & $\begin{array}{l}\mathrm{CO}_{2}, \mathrm{CH}_{4}, \mathrm{~N}_{2} \mathrm{O} \\
\mathrm{JDCs}, \mathrm{SF}_{6} \text { and } \\
\mathrm{NF}_{3}\end{array}$ & $\begin{array}{l}\text { Electricity and Industry (facilities } \geq 25 \mathrm{k} \\
\mathrm{tCO}_{2} \mathrm{e} \text { ) from } 2012 \text {, natural gas and liquid } \\
\text { fuels and transport fuels from } 2015\end{array}$ & Mandatory & $\begin{array}{l}\text { Direct and } \\
\text { indirect }\end{array}$ & - \\
\hline Alberta & $\mathrm{CO}_{2}$ & Facilities emitting $\geq 100 \mathrm{k} \mathrm{tCO}_{2}$ per year & Mandatory & Direct & - \\
\hline
\end{tabular}

Source: Own compilation based on publicly available information retrieved from related governmental websites as of 30 June 2012 .

capacity to act that way. Hence, the application as well as the withdrawal from a treaty itself, often depends above all on political and not least economic considerations. In particular, a country's reputation plays a very important role in international law and beyond doubt, has a significant impact on a country's decision to enter into a climate change treaty or a linking agreement with the EU.
Recalling the above mentioned economic preference of a common mandatory cap as shown by $[9,10]$, a realistic approach will have to concede that national governments might neither be willing to give up their sovereignty and subordinate to a global government, e.g. by transferring the competence of cap setting to a particular central authority. Nevertheless, the question has to 
Schemes with the EU ETS in a Bottom-Up Approach

Table 4. Issues regarding trading, allocation, temporal flexibility and compliance in different emissions trading schemes.

\begin{tabular}{|c|c|c|c|c|c|c|}
\hline & Allocation & Banking & Borrowing & Use of offsets & Penalty system & Price cap \\
\hline EU ETS & $\begin{array}{c}\text { Gratuitous (Grandfathering, } \\
\text { benchmarking) } \\
2005-2012 \text { : at least } \\
90 \%-95 \% \\
2013-2020: \sim 50 \%\end{array}$ & Yes & No & $\begin{array}{c}\text { JI-and } \\
\text { CDM-Offsets }\end{array}$ & $\begin{array}{c}100 € / \mathrm{tCO}_{2} \& \\
\text { delivery in } \\
\text { next period }\end{array}$ & No \\
\hline $\begin{array}{l}\text { ETS } \\
\text { Switzer- } \\
\text { land }\end{array}$ & $\begin{array}{l}\text { Gratuitous, according to the } \\
\text { firm's targets }\end{array}$ & No & No & $\begin{array}{c}\text { JI- and } \\
\text { CDM-Offsets }\end{array}$ & $\begin{array}{l}\text { From 2010: } 36 \\
\mathrm{CHF} / \mathrm{tCO}_{2}\end{array}$ & $\mathrm{CO}_{2} \operatorname{tax}: 36 € / \mathrm{tCO}_{2}$ \\
\hline JVETS & $\begin{array}{c}\text { Gratuitous, amount }=\text { base } \\
\text { year emissions, average for } \\
\text { past } 3 \text { years - committed } \\
\text { reduction }\end{array}$ & Yes & No & $\begin{array}{c}\text { JI- and } \\
\text { CDM-Offsets }\end{array}$ & $\begin{array}{l}\text { Disclosure of } \\
\text { performance \& } \\
\text { redemption of } \\
\text { subsidies for } \mathrm{CO}_{2} \\
\text { reduction }\end{array}$ & No \\
\hline IDMET & Gratuitous & Yes & Yes & $\begin{array}{c}\text { JI- and } \\
\text { CDM-Offsets }\end{array}$ & - & No \\
\hline Tokyo ETS & $\begin{array}{c}\text { Gratuitous, amount }=\text { base } \\
\text { year emissions } \mathrm{x} \\
(1 \text {-compliance factor) } \mathrm{x} \\
\text { compliance period ( } 5 \text { years })\end{array}$ & Yes & No & Domestic Offsets & $\begin{array}{l}\text { Monetary fine } \\
(¥ 500,000) \text { \& } \\
\text { requirement to reduce } \\
1.3 \text { times the shortage } \\
\text { \& disclosure of } \\
\text { performance }\end{array}$ & No \\
\hline $\begin{array}{c}\text { South } \\
\text { Korea ETS }\end{array}$ & $\begin{array}{l}\text { Gratuitous }(95 \%) \text { based on } \\
\text { historical emissions, } \\
\text { designed capacity and best } \\
\text { available technology (BAT) }\end{array}$ & - & - & CDM-Offsets & $\begin{array}{l}3 \text { times of market } \\
\text { price, disclosure of } \\
\text { performance }\end{array}$ & - \\
\hline СРМ & $\begin{array}{l}\text { Full auctioning from } 1^{\text {st }} \text { July } \\
\text { 2015; gratuitous allocation } \\
\text { for emissions-intensive } \\
\text { trade-exposed sectors }\end{array}$ & $\begin{array}{l}\text { Yes (from } \\
1^{\text {st July }} \\
2015)\end{array}$ & $\begin{array}{l}5 \% \text { of year } \\
\text { ahead } \\
\left(\text { from } 1^{\text {st }}\right. \\
\text { July } 2015)\end{array}$ & $\begin{array}{l}\text { JI-, CDM- and } \\
\text { domestic } \\
\text { ACCU-Offsets } \\
\text { from } \\
1^{\text {st }} \text { July } 2015\end{array}$ & $\begin{array}{l}\text { Strict civil and } \\
\text { criminal penalties }\end{array}$ & $\begin{array}{c}\$ \mathrm{~A} 20 / \mathrm{tCO}_{2} \text { above } \\
\text { international carbon } \\
\text { price from July } \\
2015 \text {-July } 2018 ; \\
\text { yearly increase by } \\
5 \%\end{array}$ \\
\hline $\begin{array}{l}\text { New Zea- } \\
\text { land ETS }\end{array}$ & Partial gratuitous allocation & Yes & No & $\begin{array}{l}\text { JI-, CDM-, Car- } \\
\text { bon Sinks-, } \\
\text { Kyoto-Offsets }\end{array}$ & $\begin{array}{c}30-60 \mathrm{NZ} \$ / \mathrm{tCO}_{2} \& \\
\text { delivery in next } \\
\text { period }\end{array}$ & $25 \mathrm{NZ \$} / \mathrm{tCO}_{2}$ \\
\hline RGGI & $\begin{array}{l}\text { Auctioning of approx. } 90 \% \\
\text { of allowances, allocation of } \\
\text { rest is up to individual state } \\
\text { law }\end{array}$ & Yes & No & $\begin{array}{c}\text { JI- and } \\
\text { CDM-Offsets }\end{array}$ & $\begin{array}{l}3 \text { allowances per } \\
\text { missed } \mathrm{tCO}_{2} \text { are } \\
\text { automatically } \\
\text { deducted for the } \\
\text { next period }\end{array}$ & - \\
\hline WCI & $\begin{array}{c}\text { Auctioning of approx. } 10 \% \\
\text { of allowances; rest is up to } \\
\text { individual state law }\end{array}$ & Yes & No & $\begin{array}{c}\text { JI- and } \\
\text { CDM-Offsets }\end{array}$ & $\begin{array}{l}3 \text { allowances per } \\
\text { missed } \mathrm{tCO}_{2} \text { are } \\
\text { automatically } \\
\text { deducted for the } \\
\text { next period }\end{array}$ & - \\
\hline GWSA & $\begin{array}{l}\text { At the beginning high degree } \\
\text { of free allocation, then } \\
\text { gradual shifts to auctioning }\end{array}$ & Yes & No & $\begin{array}{c}\text { JI- and } \\
\text { CDM-Offsets }\end{array}$ & $\begin{array}{l}3 \text { allowances per } \\
\text { missed } \mathrm{tCO}_{2} \text { are } \\
\text { automatically } \\
\text { deducted for the } \\
\text { next period }\end{array}$ & - \\
\hline Alberta & - & Yes & No & - & $\begin{array}{c}\text { Purchase of } \\
\text { Alberta-based offset } \\
\text { credits, Emission } \\
\text { Performance Credits } \\
\text { or pay to the Climate } \\
\text { Change and } \\
\text { Emissions } \\
\text { Management Fund }\end{array}$ & - \\
\hline
\end{tabular}

Source: Own compilation based on publicly available information retrieved from related governmental websites as of 30 June 2012. 


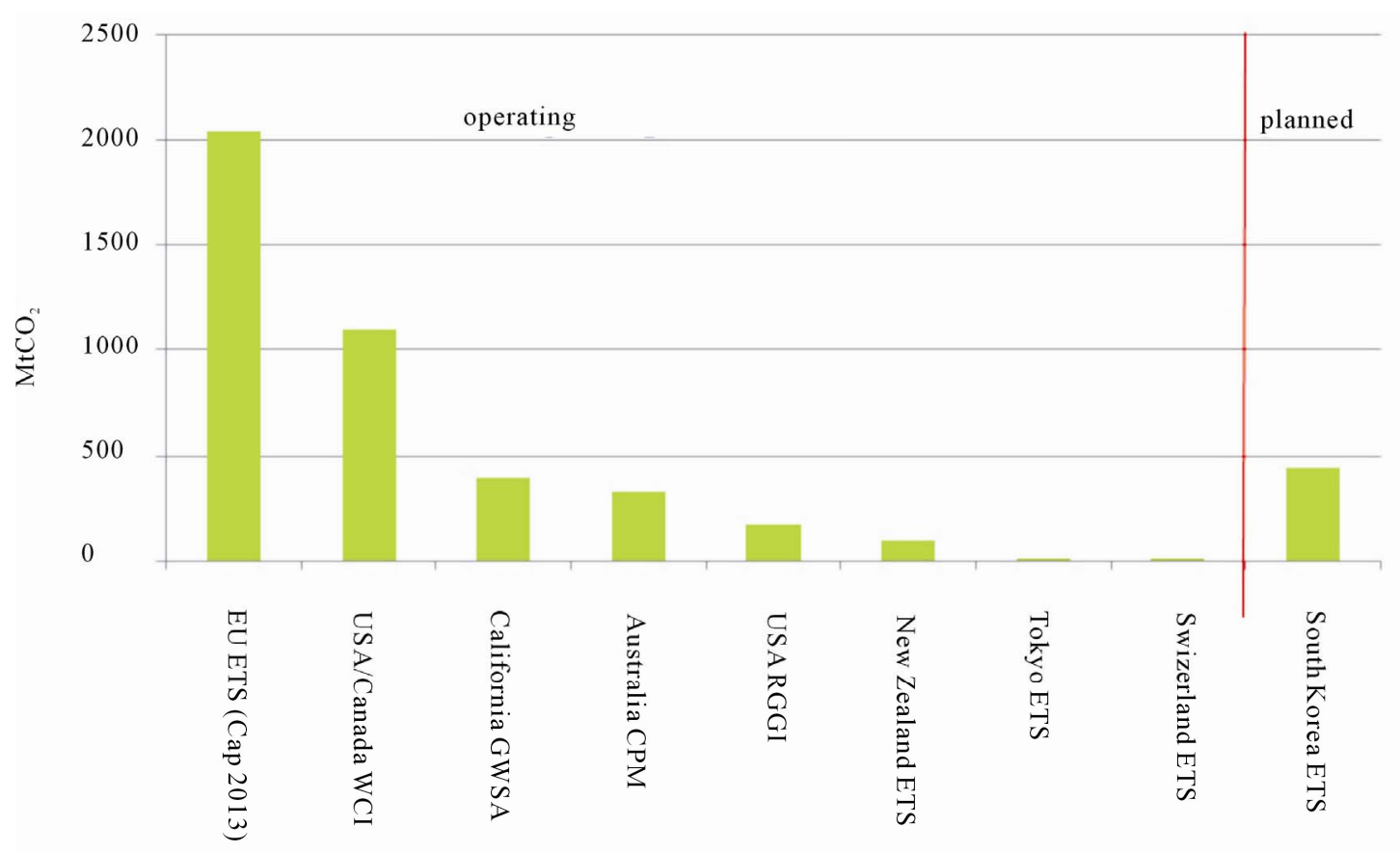

Figure 3. Covered $\mathrm{CO}_{2} \mathrm{e}$ emissions of linking candidates; Source: Own compilation based on the results of Section 3.2.

be raised which opportunities can be envisaged to settle this conflict. Answering the problem of a global common, any proposals thereto will obviously relate more or less to the field of global governance.

\subsection{Creation of a New Institution or Improvement of the UNFCCC}

In principle, a new institution could be installed by the means of bi- and/or multilateral linking agreements, which is responsible for matters that need to be dealt with concerning the linkage of ETS. These include in particular the setting of reduction targets for each participating country, the managing of the auctioning of the corresponding overall allowances if required, and the monitoring of their compliance as ultimate authority. In practice, such structures do already exist within the UNFCCC, so that it seems more reasonable to look for a way to adopt and improve these frameworks with the aim of harnessing them in a bottom-up driven system. For the latter, simplification and tightening of the UNFCCC structures seem to be especially necessary. In addition, global fairness aspects have to be taken into account more seriously, with respect to the permits allocation [11-13].

Despite such future improvements of the UNFCCC, political acceptance will be hard to attain, as Canada's recently announced withdrawal from the KP shows. Hence, even a stronger compliance system might not guarantee enduring adherence.
In this context the authors propose to uncouple the crucial matter of centralized cap-setting from the political negotiation procedure-perhaps by installing an independent scientific body for that purpose. In general the widely accepted Intergovernmental Panel on Climate Change (IPCC) seems to be predestined for this task. Based on future provisions in a follow-up treaty to the $\mathrm{KP}$ for instance, this scientific body could be assigned to appoint a nationally and politically independent executive board responsible for a science-based and comprehensive cap-setting, comprising all states involved in a globally linked ETS.

\subsection{Linking Climate and Trade}

Traditionally, international trade and climate change communities look at each other with suspicion, judging "globalisation" as key source of climate problems on the one hand and criticising that climate policies are harming trade and economic growth on the other hand. Nevertheless, a future reconciliation of both regimes might show the greatest promise concerning climate politics. For instance, the WTO constitutes one of the most effective international organisations due to compliance rules that are thoroughly implemented. Without bringing together the objectives of fostering trade and climate change, and recognising them as two sides of the same coin, effective emissions reductions measures will be slowed down significantly.

Additionally, it should be taken into account that 
every-more or less globally-linked ETS will have to face carbon-leakage problems depending inversely on the number of schemes involved [14]. Thus, such a system might in any case have to introduce some kind of adjustments and need to take WTO rules into consideration.

\section{Conclusions and Outlook}

In face of the uncertainty about a binding post-2012 climate policy agreement and thus for a consolidated topdown global emissions trading scheme, building such a system step by step by national links could be an important contribution to a sustained development of market-based climate policies.

Based on the findings of the presented evaluation of possible link ing candidates, the crucial question is whether such a bottom-up system will be able to meet the climate change challenges in an adequate manner without any centralized institution adopting certain common regulations at an international level such as the allocation of certificates within a certain cap.

The finally presented ideas of creating an independent cap-setting authority on the international level as well as the-also only touched upon-issue of reconciling trade and climate interests open up a wide field for more profound investigation. In addition, they might have to face significant political obstacles. Nevertheless, a discussion on new legal structures has to be launched urgently in order to promote the future development of international climate politics.

\section{Acknowledgements}

Financial support from the Austrian Climate and Energy Fund in the framework of the "ARCP" Program is gratefully acknowledged. The authors also thank Martin Luger for helpful suggestions.

\section{REFERENCES}

[1] T. Marauhn and A.-M. Böhringer, "Climate Policy after Copenhagen. The Future of Climate Protection According to International Law," In: J. Gundel and K. W. Lange, Eds., Climate Policy after Copenhagen-International Instruments and National Implementation, Mohr Siebeck, Tübingen, 2011, pp. 1-6.

[2] J. Peel, L. Godden and R. J. Keenan, "Climate Change Law and Governance from the 'Bottom up': Introduction to the Special Issue," Climate Law, Vol. 2, No. 4, 2011, pp. 459-468.

[3] R. Schüle and W. Sterk, "Linking Domestic Trading Schemes and the Evolution of the International Climate Regime Bottom-Up Support of Top-Down Processes? In- troduction to the Special Issue of MITI," Mitigation and Adaption Strategies for Global Change, Vol. 14, No. 5, 2009, pp. 376-378. doi:10.1007/s11027-009-9182-9

[4] M. Mace, I. Miller, C. Schwarte, J. Anderson, D. Broekhoff, R. Bradley, C. Bowyer and R. Heilmayr, "Analysis of the Legal and Organizational Issues Arising in Linking the EU Emissions Trading Scheme to Other Existing and Emerging Emissions Trading Schemes," Foundation for International Environmental Law and Development, London, Institute for European Environmental Policy Institute, Brussels, World Resources Institute, Washington, 2008.

[5] C. Hood, "Reviewing Existing and Proposed Emissions Trading Schemes," International Energy Agency, Paris, 2010. doi: $10.1787 / 5 \mathrm{~km} 4 \mathrm{hv} 3 \mathrm{mlg} 5 \mathrm{c}-\mathrm{en}$

[6] C. Fischer, "Combining Rate-Based and Cap-and-Trade Emissions Policies," Climate Policy, Vol. 3, Supplement 2, 2003, pp. S89-S103.

[7] C. Flachsland, R. Marschinski and O. Edenhofer, "Global Trading versus Linking: Architectures for International Emission Trading," Energy Policy, Vol. 37, No. 5, 2009, pp. 1637-1647. doi:10.1016/j.enpol.2008.12.008

[8] J. Jaffe and R. Stavins, "Linkage of Tradable Permit Systems in International Climate Policy Architecture (Discussion Paper 08-07)," The Harvard Project on International Climate Agreements, Cambridge, 2008. doi: $10.3386 /$ w 14432

[9] C. Helm, "International Emissions Trading with Endogenous Allowance Choices," Journal of Public Economics, Vol. 87, No. 12, 2003, pp. 2737-2747. doi:10.1016/S0047-2727(02)00138-X

[10] A. D'Amato and E. Valentini, "A Note on International Emissions Trading with Endogenous Allowance Choice," Economics Bulletin, Vol. 31, No. 2, 2011, pp. 1451-1462.

[11] J. Cao, "Beyond Copenhagen: Reconciling International Fairness, Economic Development and Climate Protection (Discussion Paper 10-44)," The Harvard Project on International Climate Agreements, Tsinghua University, Beijing, 2010.

[12] F. Ekardt and A. von Hövel, "Distributive Justice, Competitiveness, and Transnational Climate Protection: One Human-One Emission Right," Carbon \& Climate Law Review, Vol. 1, 2009, pp. 102-113.

[13] J. Onigkeit, N. Anger and B. Brouns, "Fairness Aspects of Linking the European Emissions Trading Scheme under a Long-Term Stabilization Scenario for $\mathrm{CO}_{2}$ Concentrations," Mitigation and Adaption Strategies for Global Change, Vol. 14, No. 5, 2009, pp. 477-494. doi:10.1007/s11027-009-9177-6

[14] S. Monjon and P. Quirion, "Addressing Leakage in the EU ETS: Border Adjustment or Output-Based Allocation?" Ecological Economics, Vol. 70, No. 11, 2011, pp. 1657-1971. doi:10.1016/j.ecolecon.2011.04.020 